Article

\title{
An integrated view of Greenland Ice Sheet mass changes based on models and satellite observations
}

\author{
Ruth Mottram ${ }^{1 *}$, Sebastian B. Simonsen ${ }^{2}$, Synne Høyer Svendsen ${ }^{2}$, Valentina R. Barletta ${ }^{2}$, Louise \\ Sandberg Sørensen ${ }^{2}$, Thomas Nagler ${ }^{3}$, Jan Wuite ${ }^{3}$, Andreas Groh ${ }^{4}$, Martin Horwarth ${ }^{4}$, Job \\ Rosier $^{1,5}$ and Rene Forsberg ${ }^{2}$ \\ 1 Danish Meteorological Institute, Lyngbyvej 100, Copenhagen, Denmark \\ National Space Institute, DTU Space, Geodynamics Department, Denmark \\ ENVEO IT GmbH, Innsbruck, Austria \\ Institut für Planetare Geodäsie, Technische Universität Dresden, 01062 Dresden, Germany \\ 5 Department of Geoscience and Remote Sensing, Delft University of Technology, The Netherlands \\ * Correspondence: rum@dmi.dk; Tel.: +45-39157-488
}

\begin{abstract}
The Greenland ice sheet is a major contributor to sea level rise, adding an estimated $0.47+/-0.23 \mathrm{~mm} / \mathrm{yr}$ to global mean sea level between 1991 and 2015 ([1]). Making sea level rise projections for the future and understanding the processes controlling current observed rates of sea level rise are crucially dependent on understanding the present-day state of the ice sheet. Here, we provide an overview of the current state of the mass budget of Greenland based on satellite gravimetry and remote sensing observations of surface elevation change, ice sheet velocity and calving front positions. We also combine these essential climate variables with a regional climate model (RCM) output from an ice sheet model (ISM) to gain insight into poorly understood ice sheet dynamical and surface mass processes. On average from 1992 to 2017 the ice sheet in some locations has lost up $-2.65 \mathrm{~m} / \mathrm{yr}$ in elevation based on ESA Radar altimetry analysis. Calving fronts have retreated all around Greenland since the 1990s and in only two out of 28 study locations have they remained stable. The locations of grounding lines at 5 key glaciers with floating ice tongues have remained stable over the observation period. However a detailed case study at Petermann glacier with an ice fracture model shows the sensitivity of these floating ice shelves to future climate change. GRACE gravimetric mass balance (GMB) data allows us to tie together disparate lines of evidence showing that Greenland has lost about $265+/-25 \mathrm{Gt} / \mathrm{yr}$ of ice over the period 2002 to 2015. RCM and ISM simulations show that surface mass processes dominate the overall Greenland ice sheet mass budget except for areas of fast ice sheet flow but marked differences between models and between models and observations indicate that not all processes are captured accurately, indicating areas of greater uncertainty and directions of future research for future sea level rise projections.
\end{abstract}

Keywords: Essential Climate Variables (ECV); Climate Change Initiative (CCI); Greenland Ice Sheet; Mass Budget; Cryosphere; sea level rise

\section{Introduction}

The European Space Agency's climate change initiative (ESA CCI) for Greenland ice sheet (GrIS) has made available extensive pre-processed remotely sensed datasets for scientific research. The availability of this data is invaluable in communicating the effects of climate change on the cryosphere and the likely impacts on sea level rise and human societies. The essential climate variables (ECV) specific to Greenland focus attention on the most significant processes that lead to changes in ice sheet properties and therefore sea level rise. ECVs allow both detailed process studies as well as being a 
monitoring tool to determine the present day state of the Greenland ice sheet. They also indicate the likely direction of future evolution and sources of uncertainty, particularly when combined with regional climate and ice sheet model output.

Data products include ice velocity (IV), surface elevation change (SEC), grounding line position (GLL) and calving front location (CFL) as well as gravimetric mass balance (GMB). While a number of scientific studies have already published important results for Greenland based partly or fully on the GrIS CCI data [2-5], combining the observations with numerical modelling reveals the power of the dataset to clarify important and outstanding issues in GrIS science.

In this article we summarise the current state of Greenland ice sheet mass balance and evaluate the importance of different ice sheet processes contributing to this using both observations and numerical models. Aside from simple model evaluation using satellite data, the use of numerical models in combination with satellite observations takes three forms in this review. Firstly, we use model outputs to correct and refine estimates of physical processes, for example by using solid and liquid precipitation, melt, sublimation/evaporation and temperature derived from a high resolution regional climate model (RCM), to correct SEC data for firn compaction [6] and convert into altimetric mass balance [7]. Secondly, we use observational data in combination with models to derive information on second order processes, for example by comparing surface mass balance (SMB) derived from RCMs with GMB data in order to partition mass loss from the Greenland ice sheet on a basin scale. Thirdly, we use observational data within models as a form of inversion or data assimilation to further improve model projections, for example with the use of IV data to drive models of ice fracture and iceberg calving. These hybrid model-data products show great potential in improving estimates of sea level rise, both rate and magnitude, derived from ice sheet models (ISMs) and RCMs.

\section{Background}

Greenland and the ice sheet contained on the island have been experiencing some of the highest rates of climate change on the planet [8], with observed temperature increases of $2^{\circ} \mathrm{K}$ since records began in the 1870s [9]. The contribution to sea level rise from the Greenland ice sheet results from two processes. Precipitation at the surface of the ice sheet is balanced by ice melt and runoff, with refreezing in the snowpack [10] or retention in liquid firn aquifers significantly complicating the calculation of the surface mass budget, also sometimes referred to as climatic mass budget or surface mass balance, referred to in this paper as SMB. The second component is only a mass loss component resulting from iceberg calving and ocean driven melting that has only been poorly observed in the field [11]

The ice sheet's total mass change has been estimated using a range of different methods and over a range of different periods but the reliance on numerical models of key processes such as SMB leads to significant uncertainty in estimates. Greenland mass budget was reconciled by [12] for the period 2000-2011 to be about $-237 \mathrm{Gt} / \mathrm{yr}$ or a contribution to sea level rise of $0.65 \mathrm{~mm} /$ year; for the period 2005-2011 a mass loss of $-263 \mathrm{Gt} / \mathrm{yr}$ or $0.72 \mathrm{~mm} /$ year of mean sea level rise is estimated, accounting for around a third of the average observed sea level rise of $3.1 \mathrm{~mm} /$ year (between 1993 and 2017) $[12,13]$. High interannual variability in precipitation and melt as well as calving means that the GrIS total budget and calculated sea level rise contribution is sensitive to time period chosen and to the technique used to calculate it (e.g. [12,14]).

There has been a significant increase in the amount of data available within the earth sciences including in the Greenland cryosphere in recent years as documented by for example the Promice automatic weather stations on the ice sheet as well as the NASA MEaSUREs data and ICEBRIDGE (e.g.[14,15]. The ESA CCI project has consolidated, standardised and integrated satellite remote sensing data into a format that makes high quality data accessible in a useful way for scientists. This is amply demonstrated in a number of studies already published or in press where the processed data has been used to identify significant trends and changes in ice dynamics in Greenland including 
identifying significant changes in ice velocity at large outlet glaciers [16], assessing the causes surface elevation change across the ice sheet $[2,4,5,7]$ as well as assessing the importance of different processes controlling seasonal velocity changes on the ice sheet [17].

\section{Data Products/Methods}

In this paper we briefly review 5 main data products and techniques used to derive them. We also give a brief introduction to the RCM HIRHAM5 and the ISM PISM used in the analysis of the data. In combination with ice dynamics modelling and regional climate modelling the observations allow us to partition the contribution of different processes, and regions of Greenland, to sea level rise as well as indicating uncertainties in model formulations and arising due to inadequate process understanding.

\subsection{Ice velocity}

The annual velocity maps and unprecedentedly dense IV time series of outlet glaciers provide essential information for studying temporal fluctuations and long-term trends and provide key input for ice dynamic and climate modelling. Within the framework of the ESA CCI program a system for automatic generation of ice velocity (IV) maps from repeat pass Copernicus Sentinel-1 (S1) SAR data was developed [3]. Taking full advantage of the systematic acquisition planning of S1 in Greenland - designed to cover the entire ice sheet margin at repeat intervals of 6 to 12 days augmented by ice sheet-wide winter campaigns - annual IV maps of GrIS as well as continuous timeseries of major outlet glaciers have been produced covering the entire S1 period (2014-present). Ice motion is derived from Sentinel-1 Single Look Complex (SLC) image pairs acquired in Interferometric Wide (IW) swath mode applying both coherent and incoherent iterative offset tracking. The IW mode is the standard operation mode over land surfaces including inland ice. Applying Terrain Observation by Progressive Scans (TOPS) acquisition technology, it provides a spatial resolution of about $3 \mathrm{~m} \mathrm{x}$ $22 \mathrm{~m}$ in slant range and azimuth, respectively, with a swath width of $250 \mathrm{~km}$. IV maps with $250 \mathrm{~m}$ grid spacing are produced at 6- to 12-day intervals and are also annually combined and averaged to compile a virtually gapless ice sheet-wide mean-velocity mosaic. Annual maps run from October to October roughly mimicking a glaciological SMB year. To date three consecutive annual Sentinel-1 IV maps have been produced as part of GrIS CCI. Production of the 2017/18 map is pending but the 2017/18 winter campaign map is finished (Figure 1). The maps provide detailed snap shots of contemporary ice flow in Greenland.

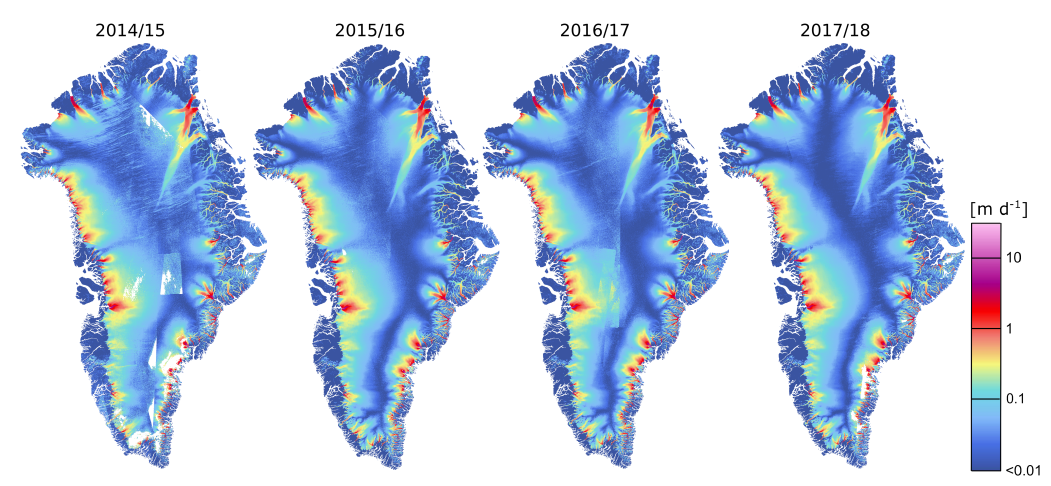

Figure 1. GrIS CCI annual ice velocity maps derived from Sentinel-1 SAR data 2014-2017 and winter campaign map 2017/18

Quality assessment of the IV retrieval algorithm was performed through internal consistency checks (for example, the stable rock test, a check on how the algorithm performs on bedrock outcrops assumed stationary), intercomparisons with other algorithms through a dedicated round-robin [18], 
ground-based data (in-situ GPS), higher resolution sensors (TerraSAR-X, COSMO-SkyMed) and independently published datasets (MEaSUREs, eg. [8,15]).

\subsection{Calving fronts}

The calving front location (CFL) marks the ever-changing terminus position of a tidewater glacier [19] subject to ice advance and iceberg calving. The CFL is a basic glacier parameter, required for purposes such as mapping glacier extent, calculating areal change or calving rates and as model domain boundary. Monitoring CFL temporal evolution is important as prolonged retreat of the calving front is a sign of changing boundary conditions and/or dynamic instability. The CFL product covers 28 key outlet glaciers around the Greenland perimeter and nearly three decades in time (1990-present). Calving fronts are extracted, at annual to seasonal intervals, through expert manual delineation of the ice-ocean boundary using geocoded satellite images in a GIS environment. Source data include primarily SAR imagery (ERS-1/2, ENVISAT, ALOS PALSAR, Sentinel-1), with temporal gaps filled using optical data (Landsat-5/7/8, Sentinel-2). To assure accurate geocoding and avoid systematic shifts in CFL of glaciers subject to strong elevation changes, a geoid is applied instead of a DEM. CFLs are available as a collection of annotated shapefiles, with detailed metadata on, amongst others, sensor and ice conditions, in the GrIS CCI database (see link at end of paper). Figure 2 shows an example of the CFL product for Sermeq Avannarleq glacier in West Greenland, depicted on a Landsat-8 image as well as time sequence of the ice front along a flowline. Prolonged retreat of the glacier terminus started in the late 1990s and it stabilized in 2010 at a new location approximately 2.5 $\mathrm{km}$ upstream. Errors in extracted ice fronts are generally within a few pixels and depend on factors such as sensor resolution and geocoding but also the presence of ice mélange in front of the glacier, which can hamper the detection of the ice front. Seasonal signals of retreat and readvance are also seen at many of these glacier fronts, making the long time series invaluable in assessing the state of the glacier dynamics. 

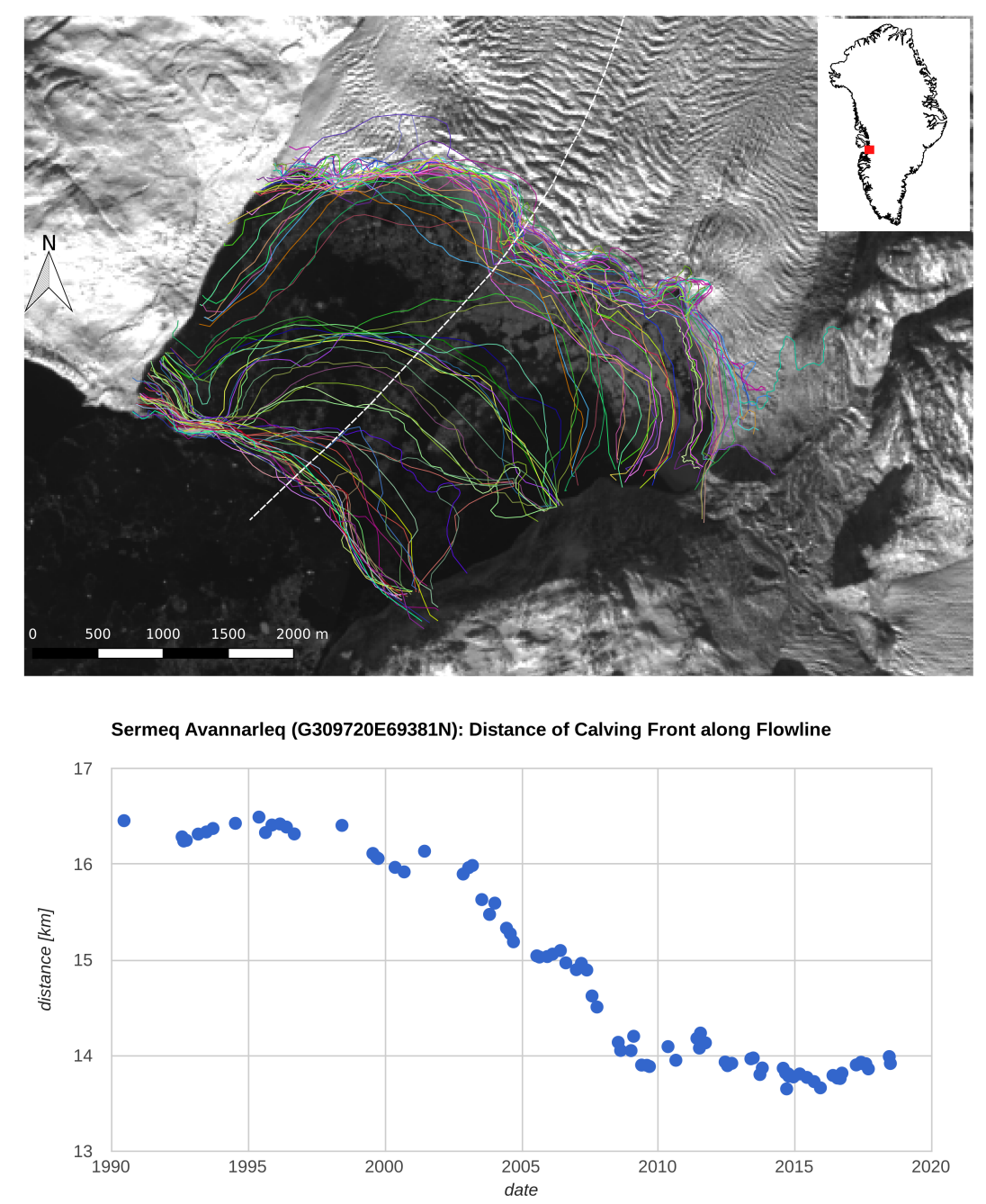

Figure 2. Top) CFLs of Sermeq Avannarleq Glacier in West Greenland from 1990 to 2018 shown as coloured lines (background: Landsat-8 image acquired at 7 October 2014, USGS). Bottom) temporal evolution of CFL plotted as distance along the central flowline (dashed white line in left figure)

\subsection{Grounding Lines}

The GrIS CCI project provides grounding line locations (GLL) for 5 key glaciers with floating termini in north Greenland: 79Fjord, Hagen, Petermann, Ryder and Zachariae. The grounding line marks the transition from grounded to floating ice and is a sensitive indicator of ice sheet stability. Locating the grounding line is critical to determine the mass flux of a marine based outlet glacier or ice sheet and monitoring changes in grounding line positions allows to identify instable regions. The GLL product is derived from InSAR data by mapping the lower and upper boundaries of the tidal flexure zone visible in double difference interferograms. These boundaries mark the seaward and landward limit of the tidal flexure zone respectively and serve as a proxy for the grounding zone [20,21]. Repeat pass data of ERS-1/2 acquired in 1995-1996 and Sentinel-1A (2015-2018) were used to map the grounding zone of the glaciers at two distinct epochs. The accuracy depends primarily on grounding zone geometry (slope), tidal amplitude, ice flow velocity and the quality of the interferogram (SNR, Coherence). Improved precision can be achieved if multiple interferograms are available; however, it is difficult to separate between horizontal displacement due to ice flow and vertical displacement due to the tidal signal, especially on fast moving outlets. The launch of Sentinel-1B, in April 2016, has reduced the repeat pass period of the Sentinel-1 mission from 12 to 6 days reducing temporal decorrelation and providing significant improvements. We apply advanced 
153

interferometric processing, using pre-determined IV to aid the co-registration, in the formation of interferograms from Sentinel-1 TOPS mode data to account for the 6- to 12-day image acquisition interval and high flow speed (up to $3 \mathrm{~m} /$ day). Figure 3 shows an interferogram of the grounding zone of Ryder Glacier in north Greenland derived from 6-day repeat pass SAR data of Sentinel-1A and $1 \mathrm{~B}$ acquired at 6,12 and 18 January 2017. The grounding zone can be recognized as a distinct band of fringes in the interferogram caused by tidal deformation.

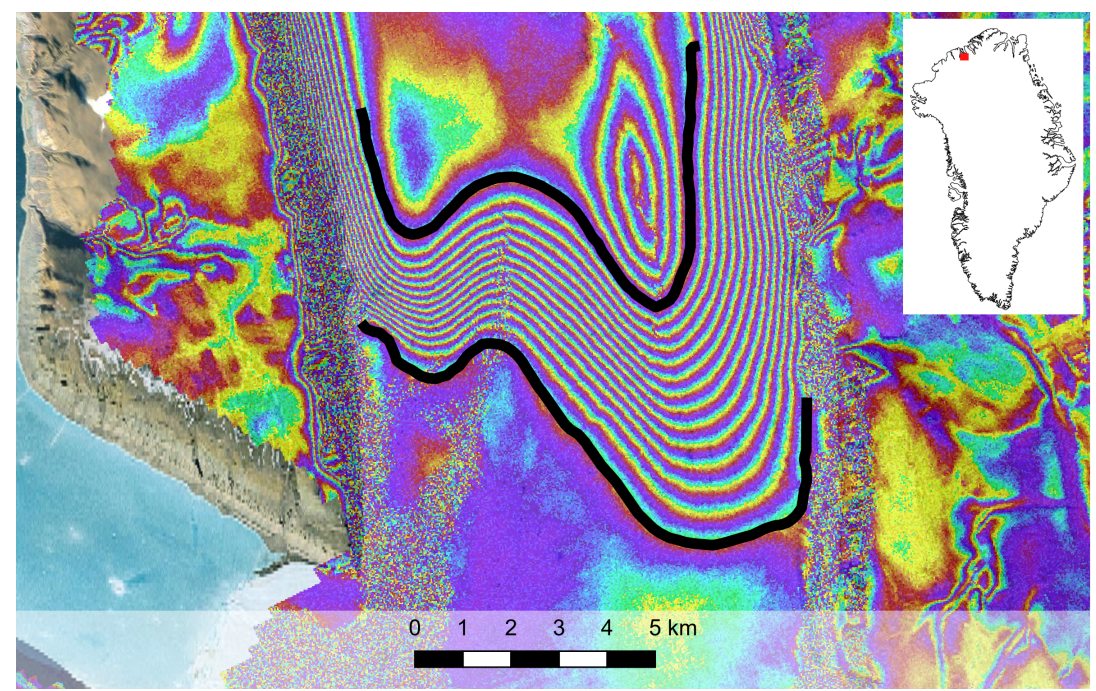

Figure 3. Geocoded double difference interferogram of the grounding zone of Ryder Glacier derived from repeat pass SAR data of Sentinel-1A and 1B acquired at 6, 12 and 18 January 2017 (background: Google Earth). Thick black lines indicate the lower and upper boundary of the tidal flexure zone. Inset shows location of Ryder Glacier in North Greenland.

\subsection{Surface Elevation Change}

The surface elevation change (SEC) is based on satellite radar altimeter observations from 1992-2017. The time series of observations is averaged as 5-year running mean estimates, to reflect climate variability and not weather. The SEC estimation uses a combination of cross-over-, repeat-track- and least-squares-methods to estimate the temporal evolution of surface elevation at a common $5 \mathrm{~km}$ uniformed grid for the entire GrIS, for more detail into the specific methods we refer the reader to the method review in [5] and mission specific papers [2,4,22-25]. Figure 4 shows the 5-year running mean estimate, for the period 2012 to 2016 in which the observed negative elevation change on the GrIS is clearly observed, particularly at the margins and in agreement with the literature [26,27]. The observed SEC is compared with RCM and ISM results (see section 3.6 and 3.7) to infer the importance of different processes. 


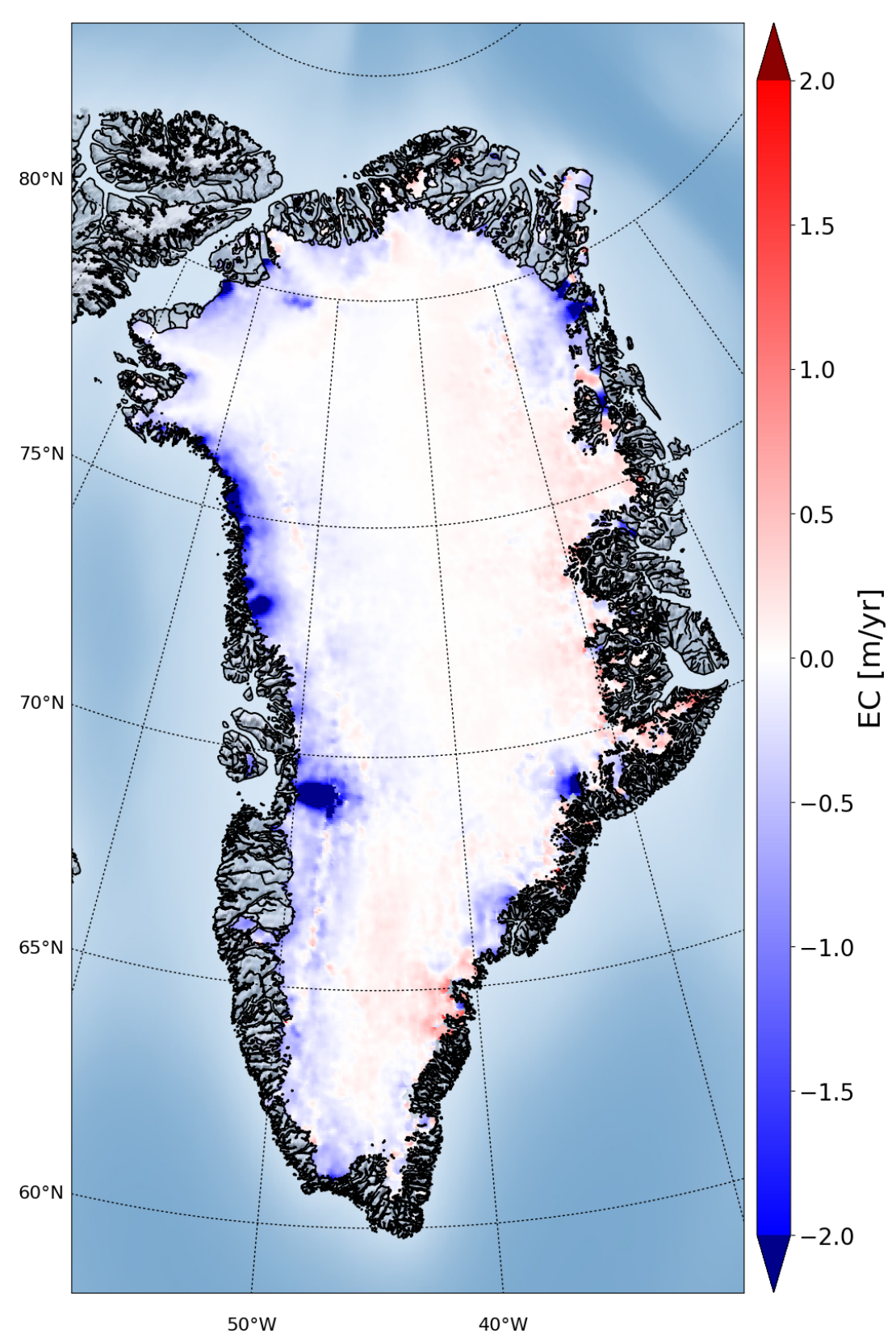

Figure 4. (Upper panel) Mean surface elevation change over the GrIS for 2016 and 2017 of the GrIS from radar altimetry

\subsection{Gravimetric Mass Balance from GRACE}

The ESA GrIS CCI project provides estimates of ice mass balance derived from the joint NASA / DLR GRACE (Gravity Recovery \& Climate Experiment) mission [28]. The GRACE mission consisted of two identical spacecrafts flying about $220 \mathrm{~km}$ apart in a polar orbit originally at $480 \mathrm{~km}$ above the Earth mapping the Earth's gravity field each month. Mapping directly the Earth's gravity field GRACE is the only remote sensing data set, which directly measures mass change, and thereby observes the ice mass balance (or equivalent sea-level rise).

The monthly solutions (level 2 product) are provided as spherical harmonic coefficients (e.g. up to degree lmax=96) by different processing centers such as CSR, GFZ, JPL and more recently also by TU Graz (ITSG-Grace2016) [29]. As a part of the ESA GrIS CCI project, Gravimetric Mass Balance (GMB) products are generated using both both ITSG-Grace2016 (2002-2017) and the new CSR RL06 solutions (2003-2016). Moreover, independent GMB products are prepared by DTU Space (DTU) [30] 
and TU Dresden (TUDR) using different approaches. The GMB products comprise mass change time series for eight drainage basins [31] and the entire GrIS as well as gridded mass balance estimates over running 5-year periods.
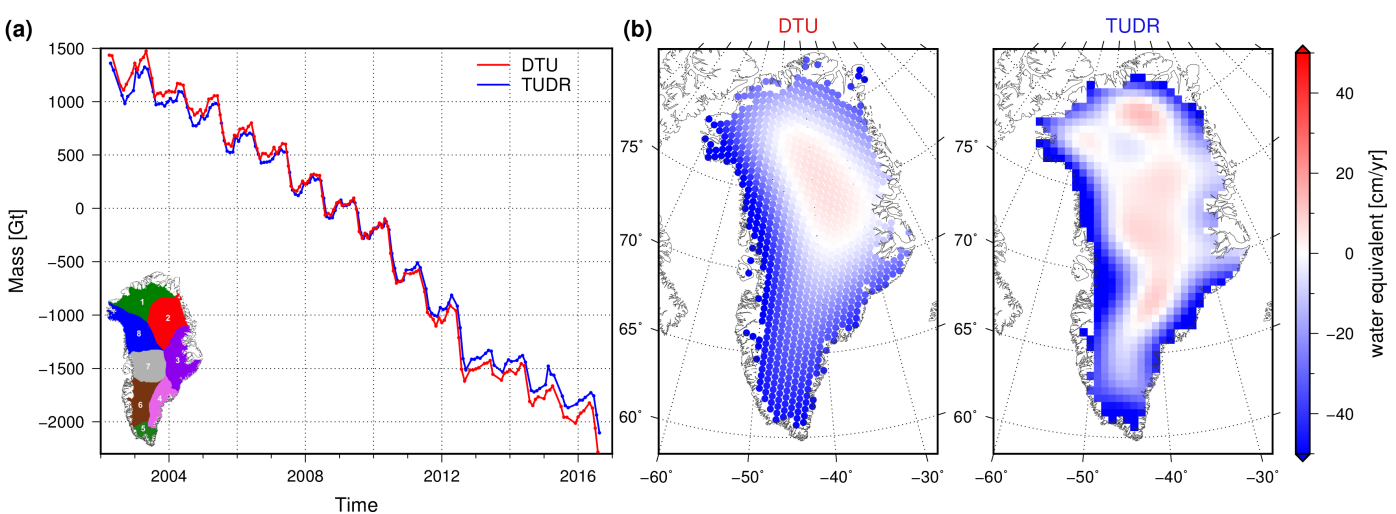

Figure 5. GMB products provided by the ESA GrIS CCI project. a) Mass change time series for the entire GrIS generated by DTU (red) and TUDR (blue). b) Ice mass trends for 2007-2011 provided by DTU (left) and TUDR (right). All products based on monthly solutions from the ITSG-Grace2016 series.

DTU applies an inversion technique to derive monthly mass changes. Gravity observations at satellite altitude are used to solve for point masses on an icosahedron grid, where each point mass represents an area with a radius of $\sim 20 \mathrm{~km}$. The ice mass changes over the whole GrIS are derived including the peripheral glaciers, which cannot discriminate in the $\sim 300 \mathrm{~km}$ resolution of GRACE. A detailed description of the approach is given in [30]. TUDR estimates monthly mass changes by applying a regional integration approach per grid cell of a $50 \times 50 \mathrm{~km}^{2}$ grid. For each grid cell a tailored sensitivity kernel was designed, which minimizes the sum of GRACE errors, derived from empirical error variance-covariance information, and signal leakage [32]. Mass change time series per drainage basin are derived by simply integrating the corresponding point masses or grid cells. Figure 5 shows two types of GMB products derived by the different approaches.

Published studies (e.g.[33]) use surface mass balance estimates derived from the RACMO regional climate model to assess the relative importance of surface and dynamic processes to ice sheet mass change. The relatively high resolution and apparently reasonable performance of such models in calculating SMB means that basin scale ice dynamics can be resolved for the GrIS. In this study we compare the results from the HIRHAM5 RCM with published results using the RACMO RCM $[1,34]$. Although the two RCMs compared here are remarkably similar (see section 4.3), this breakdown also allows us to assess processes that give rise to divergence between RCMs and the implications of these processes for assessing uncertainties in ice sheet mass balance.

\subsection{Regional Climate Model HIRHAM5}

The Regional Climate Model HIRHAM5 as described in [10,35] is used in this study as climate forcing. HIRHAM5 is run at 0.05 degrees $(5.5 \mathrm{~km})$ resolution on a rotated polar grid, and forced on the lateral boundaries with temperature, relative humidity, wind components and pressure at all 31 levels in the atmosphere every 6 hours from the ERA-Interim climate reanalysis dataset [36]. The lower boundary sea surface temperatures and sea ice applied daily are also derived from ERA-Interim data. The climate model was developed at the Danish Meteorological Institute with physical schemes modified from ECHAM5 physics [37] to be suitable for application in polar regions [38,39]. The dynamical equations are derived from the HIRLAM7 numerical weather prediction model [40]. The atmospheric radiative and turbulent fluxes drive a surface energy balance model to calculate melt rates and together with precipitation fields to derive the surface mass budget (SMB) over glaciers. The 
SMB model includes a multi-layer firn model that accounts for retention and refreezing of meltwater within the snowpack [10,39]. The effects of retention and refreezing are important to account for in calculating surface elevation change as well as having implications for total mass balance. Melt, that can be detected for example by passive microwave sensors [41] does not necessarily mean runoff and mass loss. Modelled SMB combined with GMB allows the partitioning of mass loss from Greenland into atmospherically driven melt and runoff and dynamically influenced calving and basal melt [12, $34,42,43]$.

In this study we also use the SMB calculated in HIRHAM5, together with surface temperatures, to force the parallel ice sheet model (PISM). ISMs are used to derive rates of dynamic mass change and are typically forced with a simplified surface forcing based on temperature and precipitation or, as in this study with a physically based SMB model using a surface energy budget method.

\subsection{Ice Sheet Modelling with PISM}

Given the vast amount of feedback mechanisms and interactions involving ice sheets in the climate system, ice sheet modelling and estimating future rates of ice loss is a major challenge [44,45] and has been identified as a major source of uncertainty in sea level rise projections by IPCC authors in the fifth assessment report [8]. Ice sheet models are available at a range of different degrees of complexity, from basic zero order models to hybrid models and second order models to full Stokes models [46]. Each model type has different limitations and strong points and is suitable for different types of simulations spanning a variety of temporal and spatial scales. Regardless of model complexity however, proper boundary and initial conditions are necessary, requiring observational data to be available. Also, in order to validate the models and constrain model parameters, observational data sets are essential. Here, we use SEC data to evaluate simulations of the ice sheet with the Parallel Ice Sheet Model (PISM).

PISM is an open-source thermodynamically coupled, polythermal hybrid stress balance ice sheet model [47,48], where the hybrid scheme combines the Shallow Ice Approximation (SIA) [49] and the Shallow Shelf Approximation [50]. The effective viscosity of glacier ice, $\eta$, is given by

$$
2 \eta=\frac{1}{E A}\left(\tau_{e}^{2}+\varepsilon^{2}\right)^{\frac{1-n}{2 n}}
$$

$E$ is the flow enhancement factor, $\tau_{e}$ is the effective stress, $A$ is the enthalpy-dependent rate factor and $\varepsilon$ is a small constant regularizing the flow law at low effective stresses, thereby avoiding problems with infinite viscosity at zero deviatoric stress. For the simulations presented here, $E=1.5$ and $n=3.0$ for both the SIA and the SSA case. Calving is accounted for using a mask reflecting the initial ice geometry but with no further ice dynamical feedback implemented int he model. In order to examine the effects of sliding on the ice flow, different values for the fill value for yield stress of the basal till have been tested, from a value of $2.0 \cdot 10^{5} \mathrm{~Pa}$ to $1.25 \cdot 10^{5} \mathrm{~Pa}$, the former being a very strong value, that ensures little or no sliding to amplify the flow [51]. All other model parameters related to sliding are kept constant.

The ice sheet model is run over Greenland at $2 \mathrm{~km}$ grid resolution, with initial bedrock and ice surface topography from [52] and is driven by monthly fields of surface mass balance and $2 \mathrm{~m}$ temperatures from the regional climate model HIRHAM5 (Sec. 3.6) for the period 1980-2017. Prior to the 1980-2017 simulation, we made a spinup simulation consisting of a glacial cycle run following the SeaRISE experiments [53] at 10km grid resolution followed by runs at progressively higher model resolution $(10 \mathrm{~km}-5 \mathrm{~km}-2 \mathrm{~km})$ driven by a constant annual cycle based on multi-year monthly means of the first 15 years of the HIRHAM5 1980-2017 time slice in order to bring the ice sheet close to equilibrium with the mean present-day climate of HIRHAM5. 


\section{Results and Discussion}

\subsection{Surface elevation change in models and observations}

The relatively short period of observations, compared with the long timescales of ice sheet dynamics makes for challenging evaluation of ice sheet surface elevation change due to ice dynamics. In Figure 65 year means of observed SEC are compared with the modelled SEC from the HIRHAM SMB output and the PISM modelled change. In this way the relative contributions of surface and dynamical processes to changes in SEC are decomposed.

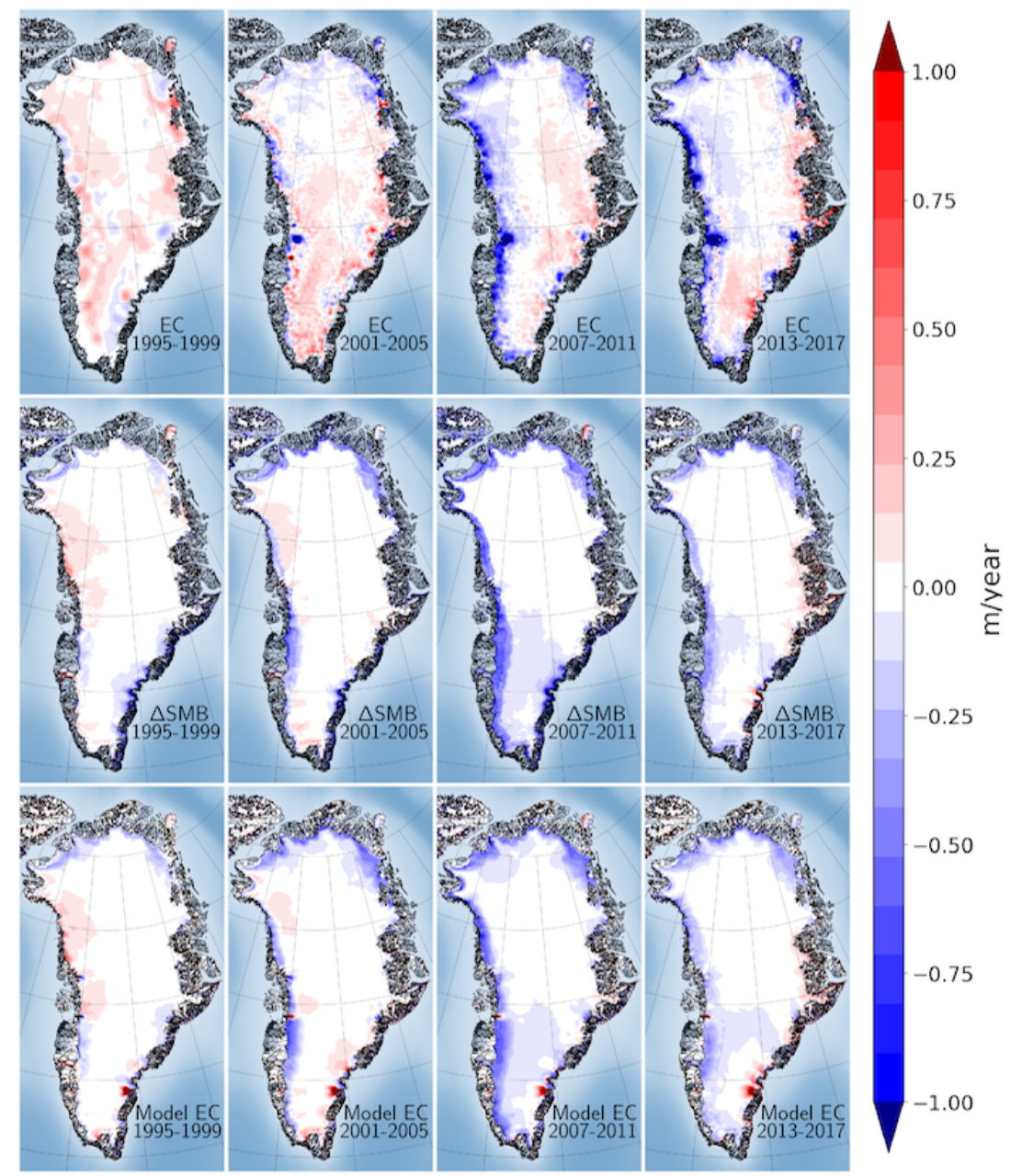

Figure 6. (Upper panel) Surface elevation of the GrIS from radar altimetry. (Middle panel) Change in surface mass balance in respect to the reference period (1982-1992). (Lower panel) Change in volume as modelled by PISM when forcing PISM with HIRHAM5 surface mass balance and temperature.

Comparison between the SEC observed from radar altimetry (upper panel) with the modelled SMB (middle panel) and modelled SEC from the ISM (lower panel) suggests that surface mass processes of precipitation and melt dominate the observed SEC. This supports analysis by [14] who also found SMB processes dominate the recent ice sheet mass budget. Around the margins of the ice sheet the modelled SMB from the RCM and SEC observations show a similar pattern of elevation change both in sign and in spatial extent. However, it is also noteworthy that the majority of the ice sheet interior shows a small surface increase in all four periods from observations, this is not reflected in the modelled SMB model, where the RCM apparently has too little precipitation. The 
observed surface elevation increase in this region may also result from ice sheet dynamic processes as suggested by [54] though the ice sheet model also does not capture this process.

There are some regions of the GrIS, mainly around basins where there are fast flowing outlet glaciers such as Jakobshavn glacier, that show a surface lowering much greater than derived from the SMB modelling. The PISM model results also show the strong influence of the surface mass balance forcing from HIRHAM though in some regions there is a discernible ice dynamic influence such as in the Jakobshavn basin as well as drainage basins feeding into the fast moving outlet glaciers of south east Greenland. However, the ISM in fact under-predicts this SEC and in some cases even has the wrong sign. This is likely to be at least in part a result of the model resolution inadequately capturing basal topography though may also reflect process parameter uncertainty that gives lower ice sheet velocities than observed in some locations as discussed in the following section. The lack of a dynamic calving parameterisation, a long-standing problem in ice sheet modelling [19], may also contribute to this underestimate in SEC as the model underestimates the increase in ice velocity gradients that lead to dynamic thinning [55] as calving rates increase.

\subsection{Modelled and Observed Ice Velocities}

In Figure 7 the mean modelled ice velocities for the winter 2014-2015 (Oct-Mar) are compared to the corresponding observed ice velocity. Figure $7 b$ ) shows the results for the low sliding case, while Figure7e) shows the sliding case. In both cases, overall structure of the flow field looks reasonable, even though the modelled velocities are too low. Ice streams are mostly properly located, even though the North Eastern Greenland Ice Stream (NEGIS) is poorly represented. This is however, a consistent feature of ISMs since NEGIS dynamics are believed to be heavily influenced by geothermal heat anomalies [56-58] an effect that is currently not accounted for in most model setups. Here, PISM's ice streams are generated by bedrock topography and a combination of sliding over the base and shear deformation of a thin till and ice layer at the base [47]. When sliding is included, see Figure. 7e), the overall ice velocity increases and the individual ice streams become more focused. Figure 7d) shows the difference in the modelled velocities. From the difference plot it is evident that the overall velocity of the ice changes very little in the two cases, but the velocity in the ice streams increases significantly and focuses the flow. Using the IV data to tune the sliding enhancement factor provides a better correspondence with the observed ice velocities.

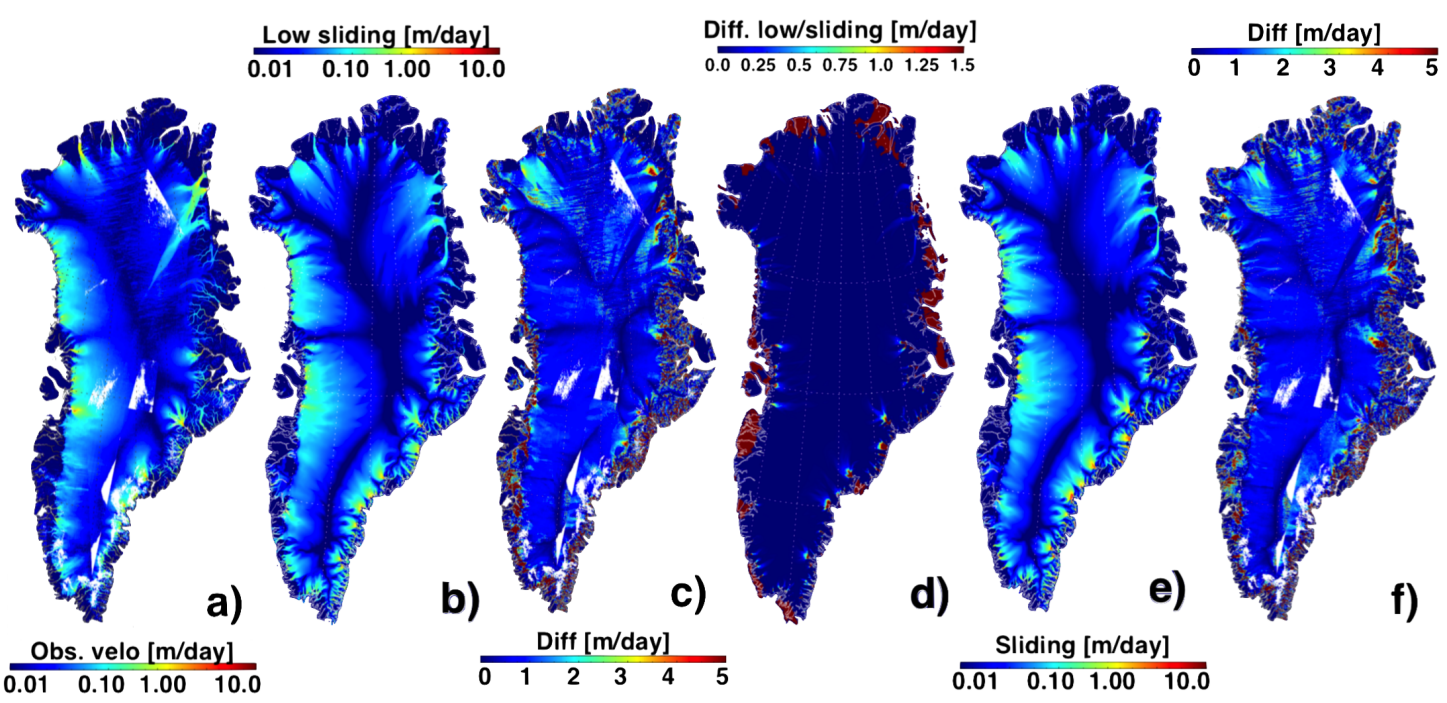

Figure 7. Ice surface velocity in the winter of 2014-2015 (Oct-Mar). a) Mean observed ice velocity. b) Modelled ice velocity in the case of low sliding. c) Difference in observed and low sliding model velocity (a vs. b). e) Modelled ice velocity with sliding included. f) Difference in observed and sliding included model velocity (a vs. e). d) The difference between the modelled ice velocities. 


\subsection{Partitioning the ice sheet budget}

To compare surface mass changes modelled by HIRHAM5 and RACMO2.3 [59] with those observed by GRACE, cumulative SMB anomalies are calculated from the monthly SMB values of both models. Long-term signal components are removed by calculating residuals w.r.t. a linear and quadratic model. In this way, the impact of differing reference periods used for deriving the cumulative SMB anomalies and of ice-dynamical mass changes included in the GMB products are largely removed. Figure 8 compares residual mass changes for eight drainage basins and the whole GrIS.

Overall there is good agreement between models for the ice sheet as a whole with some interesting regional variations. The higher amplitude positive mass balance from GRACE in basins 3, 4 and 5 also coincide with regions showing the highest precipitation inputs in Greenland - suggesting that the precipitation over the ice sheet remains a significant source of uncertainty in both models and in terms of decomposing the GRACE land and ice signals. The low SEC calculated from the SMB model compared with the observed surface elevation change in the high interior of the ice sheet also indicates that modelled precipitation from RCMs may be too low over much of the interior.

There is relatively little observational data for accumulation rates across Greenland, analysis of field data collected along the Q-transect (the Qassimiut ice lobe), one of the few consistent time series of observations, by [60] demonstrates that in basin 5, both RACMO and HIRHAM5 regional climate models overestimate precipitation over the ice sheet, particularly close to the margin. This has a consequent impact on the modelled melt rate which is therefore lower than observed due to the albedo feedback of bare ice exposure being delayed during the melt season. The underestimate of mass loss in the RCMs compared to the GMB may thus also be partly explained by this underestimate in basin 5 . Some of the highest melt rates and highest snowfall rates have been recorded by automatic weather stations on the ice sheet in Greenland in basin 5, regional climate models have struggled to reproduce these observations [60], demonstrating the value in supplementing satellite based observations and models with field measurement campaigns. Overestimating precipitation in high relief topography at the coast in turn likely leads to an underestimate of precipitation in the interior of the ice sheet.

The high amplitude mass loss in the GRACE signal, compared to the RCM data that is also especially apparent in basins 3,4 and 5 also suggests the importance of dynamical and ocean driven processes in enhancing mass loss in these regions. Basin 4 in particular has a large number of actively calving glaciers and the large mass loss recorded by the GMB from GRACE but not in the RCMs from 2005 to 2008 coincides with a period of retreat and active calving discussed further below.

Interestingly, in basins 1 and 2, where calving and ice dynamics are not as large contributors to mass loss as in other regions, modelled SMB and GMB data products match rather well. However, there are some significant differences between the two RCMs in some years in these regions as well as in region 8. We hypothesise that some of the variation is due to the albedo effect and differing albedo parameterisations as well as perhaps different precipitation rates in the two models in these locations. Northern Greenland has low precipitation rates and once darker glacier ice is exposed after fresh snow with a higher albedo melts away, large amounts of ice can be lost. A small increase in precipitation in one model compared to the other, or conversely a slightly different albedo parameterisation that increases melt in one model compared to the other, can thus have a large impact in these two basins. This analysis shows the value of detailed observations of mass change in interpreting and improving process understanding in Greenland and points to areas where improvements in regional climate models are necessary. 

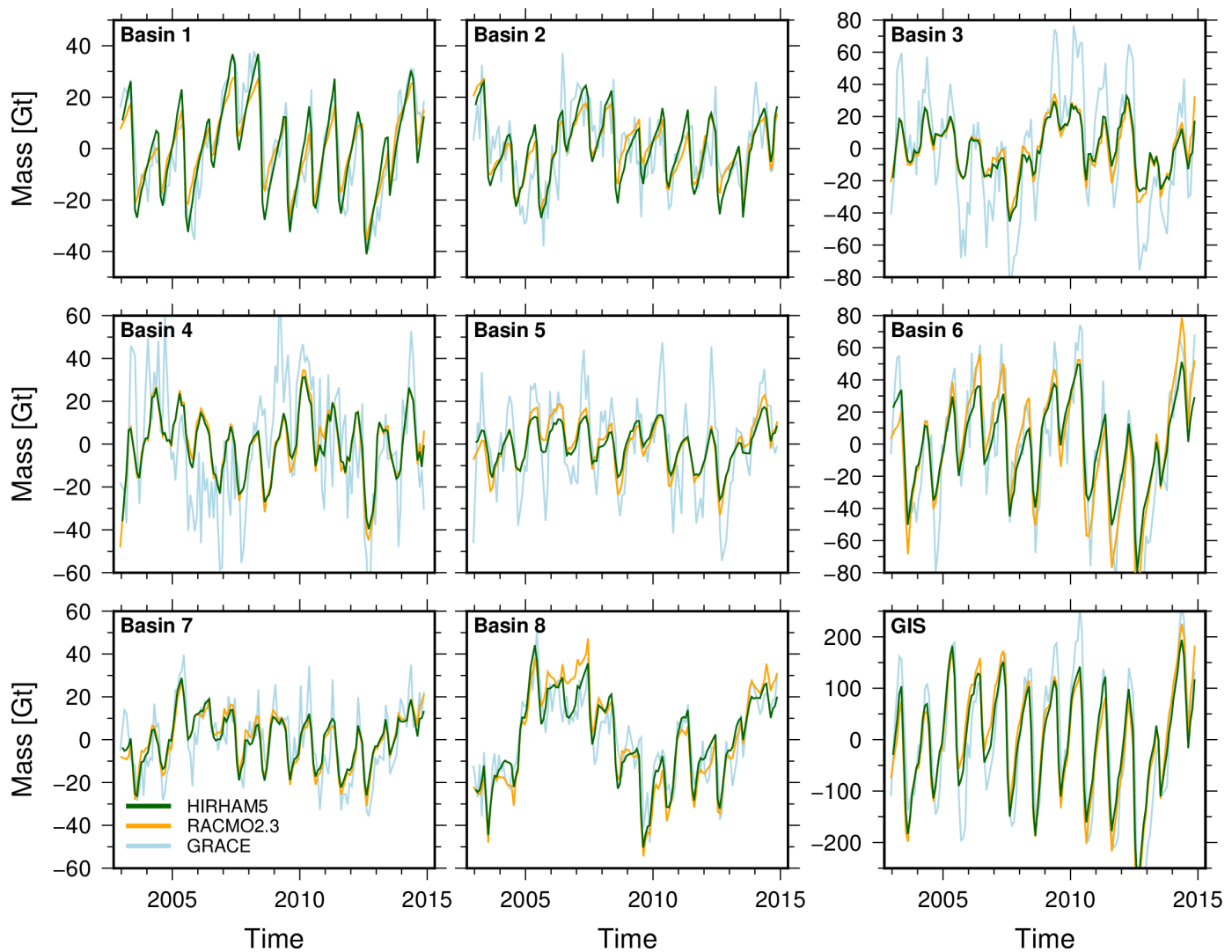

Figure 8. Inter-comparison of mass changes from GRACE (GrIS CCI GMB product) and two regional climate models (HIRHAM5 and RACMO2.3) for different drainage basins (cf. inset in Figure 5) and the entire GrIS. Mass changes are given w.r.t. a linear and quadratic model.

\subsection{Modelling mass change from Radar Altimetry}

The Ku-radar band utilized by ESA radar altimeter satellites, will penetrate the upper snow surface of ice sheets and give a return formed by volume scattering of the penetrated snow. If this snow pack suddenly incorporates ice lenses this might act as the stronger reflector and dominate the return echo. As highlighted by the 2012 extreme melt event on the Greenland [61] radar altimetry is hampered by mapping changes in the reflective horizon of the ice sheet [62], and needs to be corrected for in the interpretation of mass balance. On the other hand, the ability to penetrate the surface snow can be utilized when mapping mass change [63], assuming surface elevation variability from light and heavy snowfall events is filtered-out by the radar penetrating a finite volume in terms of mass.

Traditionally, laser altimetry mapping surface elevation changes have been converted into mass by applying a firn model $[7,64]$. Here, we omit the correction terms and use the knowledge gained about mass changes in the ICESat era by [7], to estimate a scaling factor between radar and lidar mass balance estimates at $100 \mathrm{~km}$ resolution. The low spatial resolution limits the needs for a physical model for elevation to mass change conversion, but favour a general empirical relationship as found by scaling to ICESat data. Figure 9 show the 25 year mass balance record for the Greenland ice sheet from assigning an appropriate density to the elevation change mapped by radar altimetry and our best estimate of the mass balance of the Greenland ice sheet applying the scaling to ICESat data. The GRACE record is also shown in the figure as reference. It is important to note that the method cannot map fast changes in the mass change as observed in recent years, these also are mapped into the error bounds. This is expected as wider footprint of the radar altimeter has challenges in capturing the high-slop and fast changing outlet-glaciers of the Greenland ice sheet. From the record the ice sheet is observed to be out of balance for the full 25 year record, which is in support of recent studies [13,30]. 


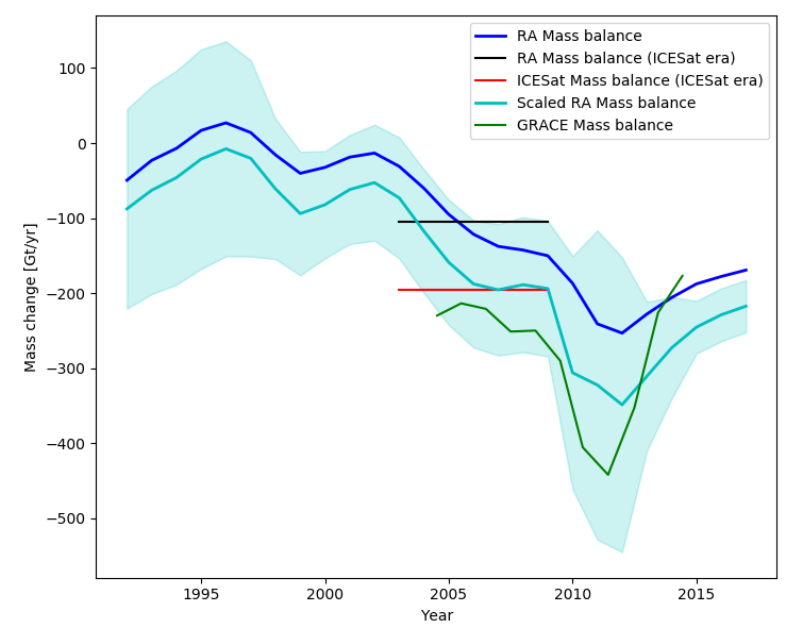

Figure 9. GrIS volume change estimates, including the raw (blue) mass change from radar altimetry (RA). The black line indicates the average radar altimetry rate during the ICESat era, the red line indicates the average rate measured by ICESat. The calibrated radar altimetry mass change rate is shown with uncertainties in cyan. For reference the GRACE mass change rate is shown in green.

\subsection{Calving glacier retreat and ice sheet mass budget}

Understanding calving processes is important as increased calving rates significantly contribute to an increase in mass loss from the Greenland ice sheet, with $[1,14,34]$ suggesting around one third of ice lost from the GrIS was the result of iceberg calving and related processes. Out of the 28 glaciers monitored by the CCI project, all except two underwent significant retreat during the period 1990 to 2016 (Figure 10).

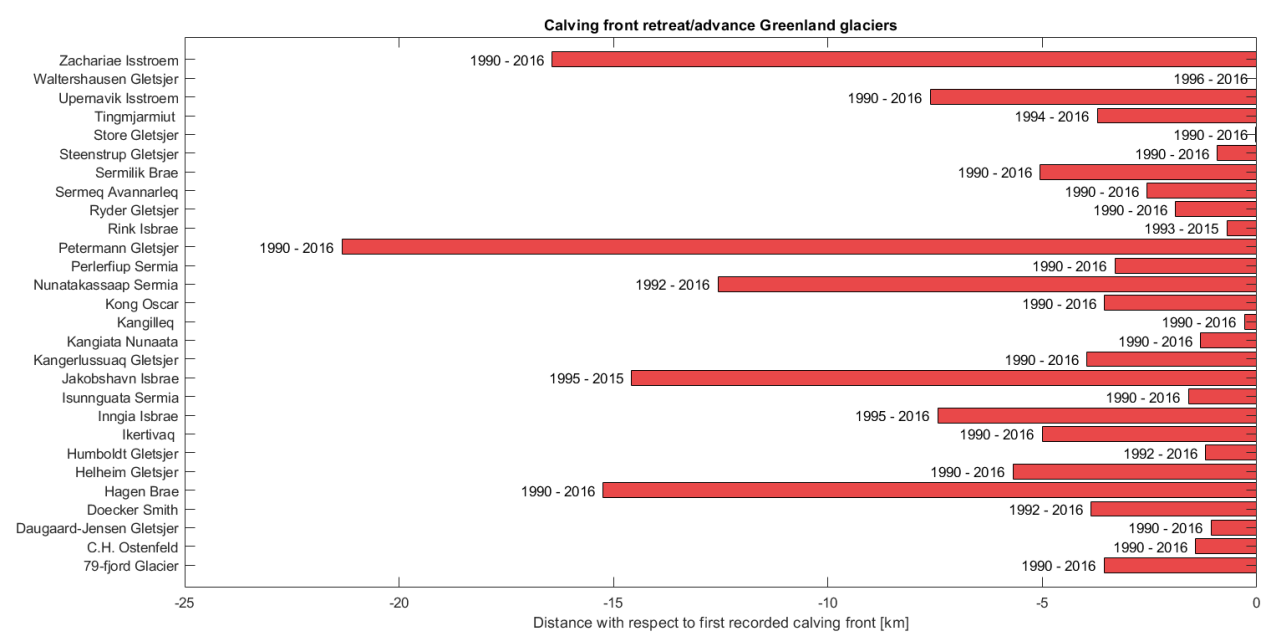

Figure 10. Cont. 


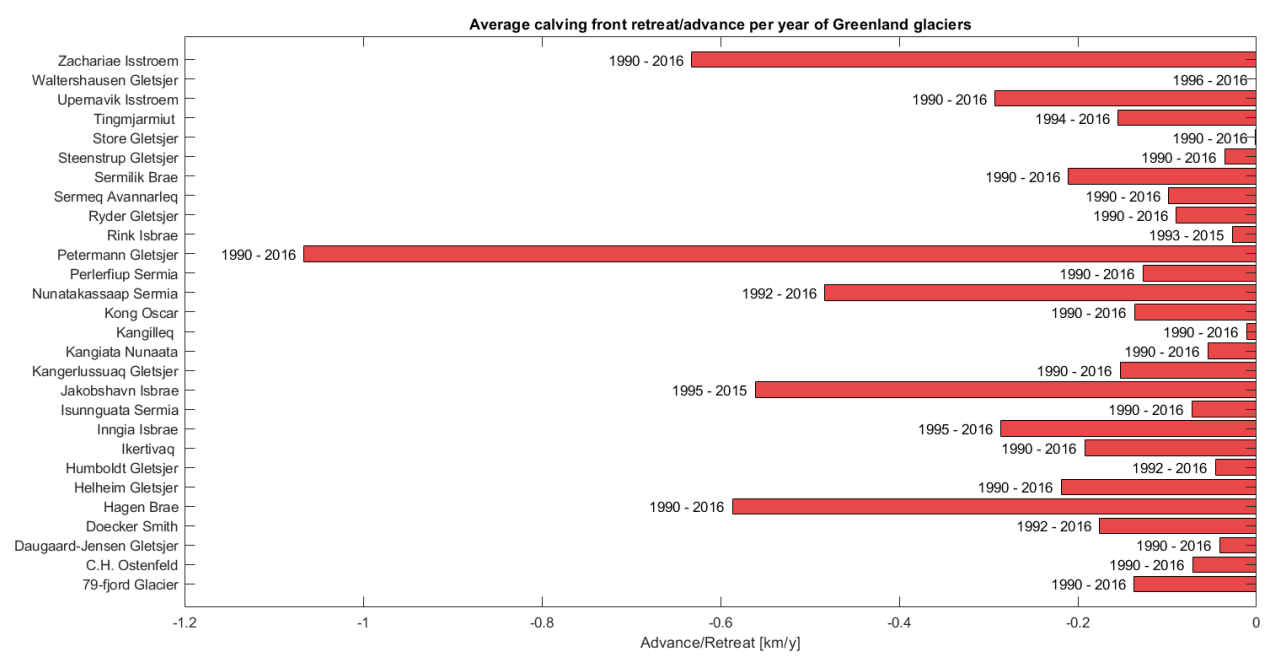

Figure 10. Total calving front retreat for each of 28 outlet glaciers between the 1990s and 2016 (top). The annually averaged rate of position change over the period (bottom).

As calving rates and calving front location (CFL) are controlled by multiple processes ([19]), the total location change and therefore rate are very sensitive to the start and end dates chosen. As Figure 11 shows, CFL is often at a stable position for a decade or longer, before a calving retreat that leads to a rapid change in position before establishing a new stable location. At Petermann glacier, a floating ice shelf rather than a tidewater glacier, the CFL gradually moves forward before a single calving event shortened the ice shelf dramatically, after which the CFL again started to move forward again. The episodic nature of changes in CFL emphasises the need for long-term monitoring to understand the behaviour of calving fronts.
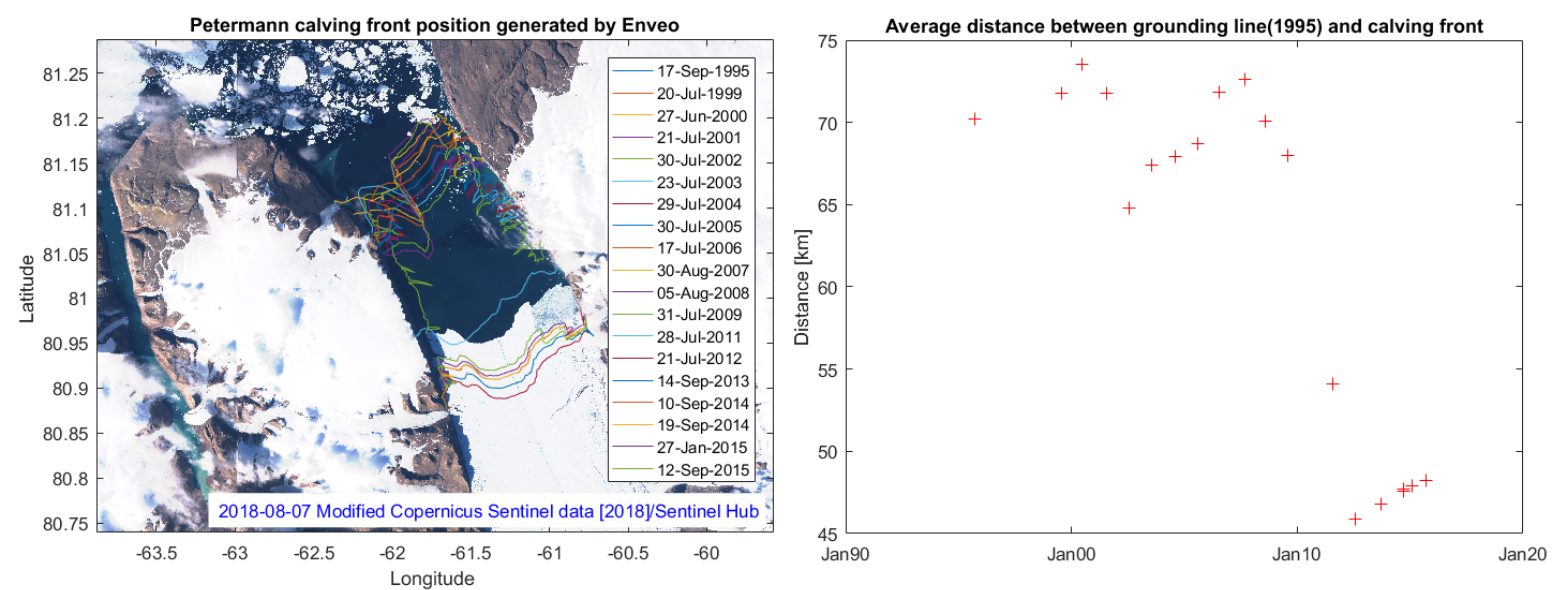

Figure 11. (left) Calving front location between 1995 and 2015. (right) Average distance between a reference grounding line of 1995 and the calving front.

The time series in the CFL dataset are at least 20 years and in some cases almost 30 years suggesting that the consistent retreat of glaciers observed around Greenland is the result of widespread climate change in the region.

\subsection{Grounding Line Stability and Ice Shelf Fracture Processes}

Most of the calving outlet glaciers in Greenland are tidewater type, that is with usually only a short and transiently floating calving front ([]benn2007calving. However, floating ice shelves 
reminiscent of the large Antarctic ice shelves do exist, although largely only in confined fjord settings unlike those found around the Antarctic continent. Plotting the grounding line locations on these floating ice shelves proved technically challenging but the stability of these locations as for example shown by [16] suggests that these glaciers are mostly stable in position at least at present day climate. Glaciers with floating ice shelves such as Petermann, 79 fjord and Zachariae Isstrøm as well as Hagen glacier are significant because each of these glacier draw down relatively large proportions of the ice sheet and so collapse could potentially lead to rapid and unstable sea level rise. For this reason, we present a case study at Petermann glacier, where multiple datasets including the ice velocity, grounding line and calving front location were combined with modelled surface runoff and an ice fracture model to give an insight into calving processes and to examine how stable the Petermann glacier ice shelf is at the present day extent (Figure 11).

Ice velocity data is used to derive strain rates that in turn are used to calculate crevasse penetration depths [65]. These have been implemented as a parameterisation in ISMs to determine calving front location and the associated dynamic feedbacks (e.g.[55]). The CCI IV data products are therefore an ideal opportunity to derive strain rates and constrain estimates of calving activity based on these (Figure $12 \mathrm{~B}$ ).

Using Glen's flow law [66] the principle stresses are calculated from the strain rates derived from IV data. Linear elastic fracture mechanics allows for the calculation of the penetration depth a crevasse will reach considering the calculated stress [65,67]. Besides the stress acting on the ice, the spacing between crevasses and the presence of water in crevasses are strong determinants of the depth a crevasse can reach and whether or not calving will occur as shown in Figure:12 C,D. The presence of water in crevasses enhances crevasse penetration and can lead to fractures propagating through the entire thickness of the ice sheet $[19,65]$.

At Petermann glacier in northern Greenland, liquid water in crevasses is present only during the summer months when the run-off is larger than zero (Figure12 A). Analysis of the ice velocity dataset shows that velocity increases significantly in summerm, likely due to melt water at the bed of the Petermann glacier reducing basal pressure as also documented at Zachariae Isstrøm [17,68]. Melt and runoff from the RCM HIRHAM5 is compared with the ice velocity and principal strain rate over the lower part of the ice shelf in Figure $12 \mathrm{~A}$ and B.
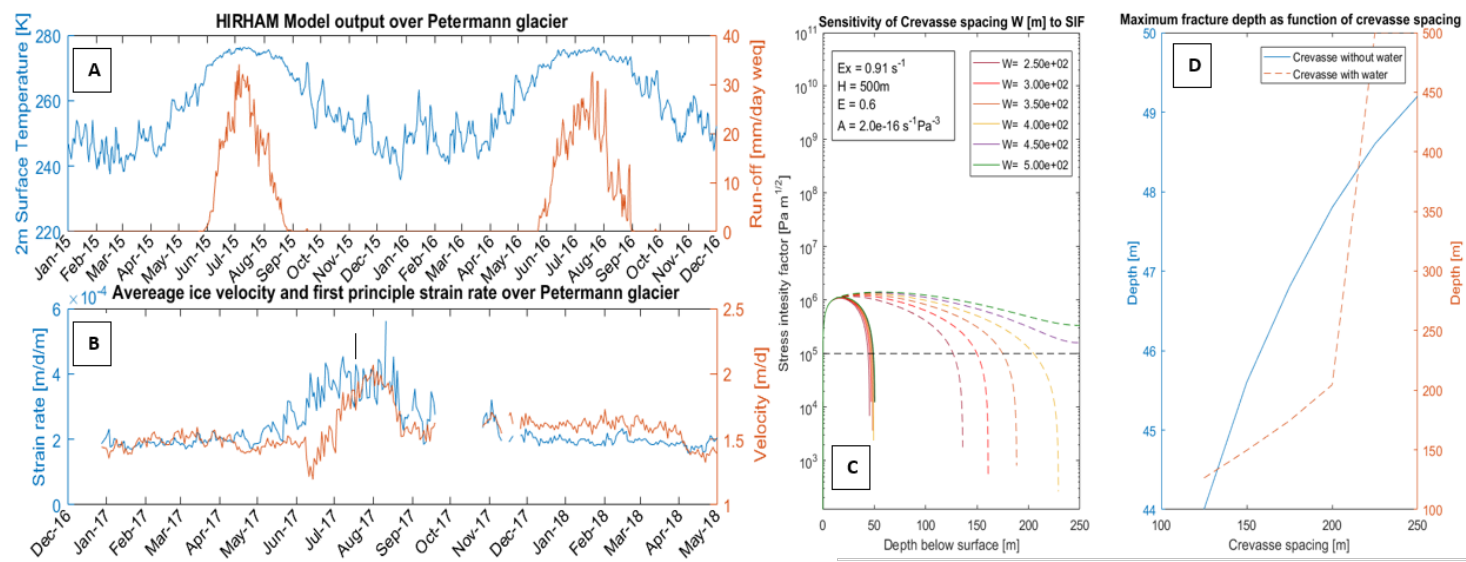

Figure 12. (a) HIRHAM model output. 2-m temperature averaged over the Petermann glacier (blue) and run-off (orange) averaged over the Petermann glacier . (b) Sentinel-1 ice velocity (orange) and first principle strain rate (blue) averaged over the Petermann glacier. (c) Stress intensity factor (SIF) at different depths for varying crevasse spacing. Solid lines correspond to dry crevasses. Dashed lines to crevasses with a water level of $10 \mathrm{~m}$ below the surface. (d) Depth a crevasse reaches when the SIF equals the fracture toughness. Dry crevasses (blue), water filled crevasses (orange). 
The importance of fracture spacing and water in enhanced fracture penetration at Petermann glacier is demonstrated by Figure $12 \mathrm{C}$ and D. The sensitivity of the fracture depth to water suggests that under a warming climate with greater meltwater production at the surface, the ice shelf may well be vulnerable to break up as other glaciers in this region have also collapsed, for example the retreat at C.H. Ostenfeldt glacier shown in Figure 10 and described along with other Greenland glaciers by [69]. Equally, higher velocities, leading to higher strain rates could lead to deeper fractures, though this effect is reduced somewhat if more crevasses open since the crevasse spacing also affects the depth of an individual fracture Figure 12D. [35,43] show a significant increase in melt water runoff across Greenland under two different climate change scenarios, indicating that floating ice shelves like Petermann glacier may become vulnerable in future, a conclusion supported by [68]. Extending this analysis at Petermann glacier to other outlet glaciers covered by the CCI GrIS datasets will also give a wider indication of the potential stability of outlet glaciers, but is beyond the scope of the current work.

\section{Outlook}

In this review paper we have given an overview of the current mass budget of the Greenland ice sheet based on models and remote sensing observations. We have also examined the relative contributions from surface mass budget processes and ice dynamics, including calving processes and grounding lines. The ESA CCI Greenland Ice Sheet observational datasets have proved to be a powerful tool in understanding and improving estimates of ice sheet mass budget and the contribution to sea level rise as well as pinpointing areas where process understanding needs to be improved. The continuation of the generated datasets and extension both back in time where possible using data from older sensors is planned as part of the CCI+ project due to commence in 2019. The existing data products will be enhanced with an ice mass flux and discharge data set that combines remote sensing and model data to give a continually updated reconciled Greenland ice sheet mass budget as used for example in [12]. The successful launch of GRACE- Follow On (GRACE-FO) and continuing developments of the next generation of RCMs and climate reanalysis capable of calculating more accurate SMB, for example the non-hydrostatic model HARMONIE-AROME already used for very high resolution $(2.5 \mathrm{~km}) \mathrm{SMB}$ calculations in Greenland [70,71] will also help to reduce process uncertainty.

\section{Conclusions}

The Greenland ice sheet has now been observed by satellite and documented in detail for almost three decades. The wealth of detailed information processed and made freely by the ESA climate change initiative has contributed to and will continue to contribute to significant advances in understanding the Greenland ice sheet.

Over the period 2002-2015 we find a gravimetric mass balance derived from GRACE for Greenland including the peripheral glaciers and ice caps of $265+/-25$ GT/year [72]. After the significant acceleration in mass loss rate in the GRACE era up to the record mass loss in the summer of 2012, Greenland has since seen a slight decrease in short-term mass loss trend.

Combining data with models is a powerful way to enhance process understanding. Decomposing GMB into basins and comparing with RCM derived SMB suggests models tend to overestimate precipitation over the ice sheet in some key basins and may also underestimate melt rates. At the same time, differences between RCM derived SMB suggests that parameterisations within the models can lead to significant regional biases in mass budget estimates.

Surface elevation has reduced across almost all of the ice sheet with a small increase in elevation in the central highest altitude parts of the ice sheet. While RCMs mostly agree with the broad trends in SEC, the inability of RCMs to reproduce the small increase in SEC in the interior and particularly in eastern Greenland suggests that precipitation is underestimated by RCMs and/or that ice dynamic processes are partly responsible. 
Analysis of model simulations from both regional climate models and ice sheet models demonstrate that while SMB is driving most of the elevation change, some basins demonstrate significant dynamic drawdown related to ice discharge through fast flowing outlet glaciers. However, the inability of the ISM to replicate this entirely suggests that running high resolution models and developing and implementing dynamic feedbacks related to calving retreat are crucial future directions for ice sheet modelling.

The active retreat followed by stabilisation of a number of calving outlets is well documented [14] and correlates with the dynamically derived SEC and with areas of relatively high velocity in the ice velocity dataset.

Analysis of grounding lines suggests that the few remaining ice shelves are currently relatively stable while analysis of the strain distribution across the ice shelf points to the importance of surface melt water in enhancing fracture propagation. Increases in melt in the future may therefore lead to increased instability and likely collapse of the remaining ice shelves around Greenland.

\section{Supplementary Materials: Data Availability}

All ESA CCI data products are available from the CCI data portal. http://esa-icesheets-greenland-cci.org/

HIRHAM5 regional climate model simulation data can be downloaded from the link given here: http://polarportal.dk/groenland/links/

Acknowledgments: ESA CCI Greenland was funded via ESA-ESRIN contract number 4000104815/11/I-NB. HIRHAM5 regional climate model simulations were carried out by Ruth Mottram with funding from the European Research Council under the European Community's Seventh Framework Programme (FP7/ 2007-2013)/ERC grant agreement 610055 as part of the ice2ice project.

Author Contributions: RM and SBS conceived and designed the outline for the paper. RM ran the HIRHAM5 regional climate model and analysed the output. SBS and LSS derived altimetry results. AG and VRB estimated the Mass Balance from GRACE with input from MH. SHS performed ice sheet model study and comparisons between ice sheet model output and observations. RF lead the ESA CCI project for the Greenland Ice Sheet. TN and JW derived the ice velocity results. JR and RM developed and ran the calving and ice fracture model. All authors contributed to writing the paper and analyzing the results.

Conflicts of Interest: The authors declare no conflict of interest.

\section{References}

1. $\quad$ van den Broeke, M.R.; Enderlin, E.M.; Howat, I.M.; Kuipers Munneke, P.; Noël, B.P.Y.; van de Berg, W.J.; van Meijgaard, E.; Wouters, B. On the recent contribution of the Greenland ice sheet to sea level change. The Cryosphere 2016, 10, 1933-1946.

2. $\quad$ Sørensen, L.S.; Simonsen, S.B.; Meister, R.; Forsberg, R.; Levinsen, J.F.; Flament, T. Envisat-derived elevation changes of the Greenland ice sheet, and a comparison with ICESat results in the accumulation area. Remote Sensing of Environment 2015, 160, 56-62.

3. Nagler, T.; Rott, H.; Hetzenecker, M.; Wuite, J.; Potin, P. The Sentinel-1 Mission: New Opportunities for Ice Sheet Observations. Remote Sensing 2015, 7, 9371-9389.

4. Simonsen, S.B.; Sørensen, L.S. Implications of changing scattering properties on Greenland ice sheet volume change from Cryosat-2 altimetry. Remote Sensing of Environment 2017, 190, 207-216.

5. Sandberg Sørensen, L.; Simonsen, S.B.; Forsberg, R.; Khvorostovsky, K.; Meister, R.; Engdahl, M.E. 25 years of elevation changes of the Greenland Ice Sheet from ERS, Envisat, and CryoSat-2 radar altimetry. Earth and Planetary Science Letters 2018, 495, 234-241.

6. Simonsen, S.B.; Stenseng, L.; Ađalgeirsdóttir, G.; Fausto, R.S.; Hvidberg, C.S.; Lucas-Picher, P. Assessing a multilayered dynamic firn-compaction model for Greenland with ASIRAS radar measurements. Journal of Glaciology 2013, 59, 545-558.

7. Sørensen, L.S.; Simonsen, S.B.; Nielsen, K.; Lucas-Picher, P.; Spada, G.; Adalgeirsdottir, G.; Forsberg, R.; Hvidberg, C.S. Mass balance of the Greenland ice sheet (2003-2008) from ICESat data - the impact of interpolation, sampling and firn density. The Cryosphere 2011, 5, 173-186.

8. Vaughan, D.G.; Comiso, J.C.; Allison, I.; Carrasco, J.; Kaser, G.; Kwok, R.; Mote, P.; Murray, T.; Paul, F.; Ren, J.; others. Observations: cryosphere. Climate change 2013, 2103, 317-382. 
9. Cappelen, J. Greenland-DMI historical climate data collection 1784-2017. Danish Meteorological Institue Report 18-04 2017.

10. Langen, P.L.; Fausto, R.S.; Vandecrux, B.; Mottram, R.H.; Box, J.E. Liquid Water Flow and Retention on the Greenland Ice Sheet in the Regional Climate Model HIRHAM5: Local and Large-Scale Impacts. Frontiers in Earth Science 2017, 4.

11. Rignot, E.; Fenty, I.; Xu, Y.; Cai, C.; Kemp, C. Undercutting of marine-terminating glaciers in West Greenland. Geophysical Research Letters, 42, 5909-5917, [https://agupubs.onlinelibrary.wiley.com/doi/pdf/10.1002/2015GL064236].

12. Shepherd, A.; Ivins, E.R.; A, G.; Barletta, V.R.; Bentley, M.J.; Bettadpur, S.; Briggs, K.H.; Bromwich, D.H.; Forsberg, R.; Galin, N.; Horwath, M.; Jacobs, S.; Joughin, I.; King, M.A.; Lenaerts, J.T.M.; Li, J.; Ligtenberg, S.R.M.; Luckman, A.; Luthcke, S.B.; McMillan, M.; Meister, R.; Milne, G.; Mouginot, J.; Muir, A.; Nicolas, J.P.; Paden, J.; Payne, A.J.; Pritchard, H.; Rignot, E.; Rott, H.; Sorensen, L.S.; Scambos, T.A.; Scheuchl, B.; Schrama, E.J.O.; Smith, B.; Sundal, A.V.; van Angelen, J.H.; van de Berg, W.J.; van den Broeke, M.R.; Vaughan, D.G.; Velicogna, I.; Wahr, J.; Whitehouse, P.L.; Wingham, D.J.; Yi, D.; Young, D.; Zwally, H.J. A Reconciled Estimate of Ice-Sheet Mass Balance. Science 2012, 338, 1183-1189.

13. WCRP Global Sea Level Budget Group. Global Sea Level Budget 1993\&amp;ndash;Present. Earth System Science Data Discussions 2018, pp. 1-88.

14. Enderlin, E.M.; Howat, I.M.; Jeong, S.; Noh, M.J.; Angelen, J.H.; Broeke, M.R. An improved mass budget for the Greenland ice sheet. Geophysical Research Letters, 41, 866-872, [https://agupubs.onlinelibrary.wiley.com/doi/pdf/10.1002/2013GL059010].

15. Joughin, I.; Fahnestock, M.; Kwok, R.; Gogineni, P.; Allen, C. Ice flow of Humboldt, Petermann and Ryder Gletscher, northern Greenland. Journal of Glaciology 1999, 45, 231-241.

16. Hogg, A.E.; Shepherd, A.; Gourmelen, N.; Engdahl, M. Grounding line migration from 1992 to 2011 on Petermann Glacier, North-West Greenland. Journal of Glaciology 2016, 62, 1104-1114.

17. Rathmann, N.M.; Hvidberg, C.S.; Solgaard, A.M.; Grinsted, A.; Gudmundsson, G.H.; Langen, P.L.; Nielsen, K.P.; Kusk, A. Highly temporally resolved response to seasonal surface melt of the Zachariae and 79N outlet glaciers in northeast Greenland. Geophysical Research Letters, 44, 9805-9814, [https://agupubs.onlinelibrary.wiley.com/doi/pdf/10.1002/2017GL074368].

18. Boncori, J.P.M.; Andersen, M.L.; Dall, J.; Kusk, A.; Kamstra, M.; Andersen, S.B.; Bechor, N.; Bevan, S.; Bignami, C.; Gourmelen, N.; Joughin, I.; Jung, H.S.; Luckman, A.; Mouginot, J.; Neelmeijer, J.; Rignot, E.; Scharrer, K.; Nagler, T.; Scheuchl, B.; Strozzi, T. Intercomparison and Validation of SAR-Based Ice Velocity Measurement Techniques within the Greenland Ice Sheet CCI Project. Remote Sensing 2018, 10, 929.

19. Benn, D.I.; Warren, C.R.; Mottram, R.H. Calving processes and the dynamics of calving glaciers. Earth-Science Reviews 2007, 82, 143-179.

20. Rignot, E.; Velicogna, I.; van den Broeke, M.R.; Monaghan, A.; Lenaerts, J.T. Acceleration of the contribution of the Greenland and Antarctic ice sheets to sea level rise. Geophysical Research Letters 2011, 38.

21. Rignot, E.; Mouginot, J.; Scheuchl, B. Antarctic grounding line mapping from differential satellite radar interferometry: GROUNDING LINE OF ANTARCTICA. Geophysical Research Letters 2011, 38, n/a-n/a.

22. Davis, C.; Ferguson, A. Elevation change of the Antarctic ice sheet, 1995-2000, from ERS-2 satellite radar altimetry. IEEE Transactions on Geoscience and Remote Sensing 2004, 42, 2437-2445.

23. Johannessen, O.M. Recent Ice-Sheet Growth in the Interior of Greenland. Science 2005, 310, 1013-1016.

24. Kirill S. Khvorostovsky. Merging and Analysis of Elevation Time Series Over Greenland Ice Sheet From Satellite Radar Altimetry. IEEE Transactions on Geoscience and Remote Sensing 2012, 50, 23-36.

25. Levinsen, J.; Khvorostovsky, K.; Ticconi, F.; Shepherd, A.; Forsberg, R.; Sørensen, L.; Muir, A.; Pie, N.; Felikson, D.; Flament, T.; Hurkmans, R.; Moholdt, G.; Gunter, B.; Lindenbergh, R.; Kleinherenbrink, M. ESA ice sheet CCI: derivation of the optimal method for surface elevation change detection of the Greenland ice sheet - round robin results. International Journal of Remote Sensing 2015, 36, 551-573.

26. Velicogna, I.; Wahr, J. Acceleration of Greenland ice mass loss in spring 2004. Nature 2006, 443, 329-331.

27. Svendsen, P.; Andersen, O.; Nielsen, A. Acceleration of the Greenland ice sheet mass loss as observed by GRACE: Confidence and sensitivity. Earth and Planetary Science Letters 2013, 364, 24-29.

28. Tapley, B.; Bettadpur, S.; Watkins, M.; Reigber, C. The gravity recovery and climate experiment: Mission overview and early results. Geophysical Research Letters 2004, 31, L09607. 
29. Mayer-Gürr, T.; Behzadpour, S.; Ellmer, M.; Kvas, A.; Klinger, B.; Zehentner, N. ITSG-Grace2016 Monthly and Daily Gravity Field Solutions from GRACE. GFZ Data Services 2016.

30. Barletta, V.R.; Sørensen, L.S.; Forsberg, R. Scatter of mass changes estimates at basin scale for Greenland and Antarctica. The Cryosphere 2013, 7, 1411-1432.

31. Zwally, H.; Giovinetto, M.; Beckley, M.; Saba, J. Antarctic and Greenland Drainage Systems; 2012.

32. Groh, A.; Horwath, M. The method of tailored sensitivity kernels for GRACE mass change estimates. Geophysical Research Abstracts 2016, 18, EGU2016-12065.

33. Sasgen, I.; van den Broeke, M.; Bamber, J.; Rignot, E.; Sørensen, L.; Wouters, B.; Martinec, Z.; Velicogna, I.; Simonsen, S. Timing and origin of recent regional ice-mass loss in Greenland. Earth and Planetary Science Letters 2012, 333-334, 293-303.

34. van den Broeke, M.; Bamber, J.; Ettema, J.; Rignot, E.; Schrama, E.; van de Berg, W.J.; van Meijgaard, E.; Velicogna, I.; Wouters, B. Partitioning Recent Greenland Mass Loss. Science 2009, 326, 984-986.

35. Mottram.; Boberg.; Langen.; Yang.; Rodehacke.; Christensen.; Madsen. Surface Mass balance of the Greenland ice Sheet in the Regional Climate Model HIRHAM5: Present State and Future Prospects. Low temperature science $2017,75,1-11$.

36. Dee, D.P.; Uppala, S.M.; Simmons, A.; Berrisford, P.; Poli, P.; Kobayashi, S.; Andrae, U.; Balmaseda, M.; Balsamo, G.; Bauer, d.P.; others. The ERA-Interim reanalysis: Configuration and performance of the data assimilation system. Quarterly Journal of the royal meteorological society 2011, 137, 553-597.

37. Roeckner, E.; Oberhuber, J.M.; Bacher, A.; Christoph, M.; Kirchner, I. ENSO variability and atmospheric response in a global coupled atmosphere-ocean GCM. Climate Dynamics 1996, 12, 737-754.

38. Rae, J.G.L.; Aðalgeirsdóttir, G.; Edwards, T.L.; Fettweis, X.; Gregory, J.M.; Hewitt, H.T.; Lowe, J.A.; Lucas-Picher, P.; Mottram, R.H.; Payne, A.J.; Ridley, J.K.; Shannon, S.R.; van de Berg, W.J.; van de Wal, R.S.W.; van den Broeke, M.R. Greenland ice sheet surface mass balance: evaluating simulations and making projections with regional climate models. The Cryosphere 2012, 6, 1275-1294.

39. Langen, P.L.; Mottram, R.H.; Christensen, J.H.; Boberg, F.; Rodehacke, C.B.; Stendel, M.; van As, D.; Ahlstrøm, A.P.; Mortensen, J.; Rysgaard, S.; Petersen, D.; Svendsen, K.H.; Aðalgeirsdóttir, G.; Cappelen, J. Quantifying Energy and Mass Fluxes Controlling Godthåbsfjord Freshwater Input in a 5-km Simulation (1991-2012). Journal of Climate 2015, 28, 3694-3713.

40. Eerola, K. Twenty-one years of verification from the HIRLAM NWP system. Weather and Forecasting 2013, $28,270-285$.

41. Mote, T.L.; Anderson, M.R. Variations in snowpack melt on the Greenland ice sheet based on passive-microwave measurements. Journal of Glaciology 1995, 41, 51-60.

42. Ettema, J.; van den Broeke, M.R.; van Meijgaard, E.; van de Berg, W.J.; Bamber, J.L.; Box, J.E.; Bales, R.C. Higher surface mass balance of the Greenland ice sheet revealed by high-resolution climate modeling. Geophysical Research Letters 2009, 36.

43. Fettweis, X.; Franco, B.; Tedesco, M.; van Angelen, J.H.; Lenaerts, J.T.M.; van den Broeke, M.R.; Gallae, $\mathrm{H}$. Estimating the Greenland ice sheet surface mass balance contribution to future sea level rise using the regional atmospheric climate model MAR. The Cryosphere 2013, 7, 469-489.

44. Vizcaino, M. Ice sheets as interactive components of Earth System Models: progress and challenges. WIRES Climate Change 2014, 5, 557-568.

45. Goelzer, H.; Robinson, A.; Seroussi, H.; van de Wal, R.S. Recent Progress in Greenland Ice Sheet Modelling. Current Climate Change Reports 2017, 3, 291-302.

46. Kirchner, N.; Hutter, K.; Jakobsson, M.; Gyllencreutz, R. Capabilities and limitations of numerical ice sheet models; a discussion for Earth-scientists and modelers. Quaternary Science Reviews 2011, 30, 3691-3704.

47. Bueler, E.; Brown, J. The shallow shelf approximation as a 'sliding law' in a thermomechanically coupled ice sheet model. Journal of Geophysical Research 2009, 114, 1-21.

48. Aschwanden, A.; Bueler, E.; Khroulev, C.; Blatter, H. An enthalpy formulation for glaciers and ice sheets. Journal of Glaciology 2012, 58, 441-457.

49. Theoretical Glaciology: Mateial Science of Ice and the Mechanics of Glaciers and Ice Sheets; Number 1 in Mathematical Approaches to Geophysics, Springer, 1983.

50. Morland, L. Plane and Radial Ice-Shelf Flow with Prescirpbed Temperature Profile. In Dynamics of the West Antarctic Ice Sheet; van der Veen, C.J. and Oelemans, J.., Ed.; D. Reidel Publishing Company, 1987.

51. Khroulev, C.; PISM authors. PISM, a Parallel Ice Sheet model: User's manual; 2015. 
52. Bamber, J.; Layberry, R.; Gogenini, S. A new ice thickness and bed data set for the Greenland ice sheet1: Measurement, data reduction, and errors. Journal of Geophysical Research 2001, 106, 33773-33780.

53. Nowicki, S.; Bindschadler, R.A.; Abe-Ouchi, A.; Aschwanden, A.; Bueler, E.; Choi, H.; Fastook, J.; Granzow, G.; greve, R.; Gutowski, G.; Herzfeld, U.; Jackson, C.; Johnson, J.; Khroulev, C.; Larour, E.; Levermann, A.; Lipscomb, W.H.; Martin, M.A.; Morlighem, M.; Parizek, B.R.; Pollard, D.; Price, S.F.; Ren, D.; Rignot, E.; Saito, F.; Sato, T.; Seddik, H.; Seoussi, H.; Takahashi, K.; Walker, R.; Wang, W.L. Insight into spatial sensitivities of ice mass response to environmental change from the SeaRISE ice sheet modeling project II: Greenland. Journal of Geophysical Research 2013, 118, 1025-1044.

54. Colgan, W.; Rajaram, H.; Abdalati, W.; McCutchan, C.; Mottram, R.; Moussavi, M.S.; Grigsby, S. Glacier crevasses: Observations, models, and mass balance implications: Glacier Crevasses. Reviews of Geophysics 2016, 54, 119-161.

55. Nick, F.; Van Der Veen, C.; Vieli, A.; Benn, D. A physically based calving model applied to marine outlet glaciers and implications for the glacier dynamics. Journal of Glaciology 2010, 56, 781-794.

56. Fahnestock, M.; Abdalati, W.; Joughin, I.; Brozena, J.; Gogineni, P. High Geothermal Heat Flow, Basal Melt, and the Origin of Rapid Ice Flow in Central Greenland. Science 2001, 294, 2338-2342.

57. Christanson, K.; Peters, L.E.; Alley, R.B.; Anandakrishnan, S.; Jacobel, R.W.; Riverman, K.L.; Muto, A.; Keisling, Benjamin, A. Dilatant till facilitates ice-stream flow in northeast Greenland. Earth and Planetary Science Letters 2014, 401, 57-69.

58. Rogozhina, I.; Petrunin, A.G.; P.M, V.A.; Steinberger, B.; Johnson, J.V.; Kaban, M.K.; Reinhard, C.; Rickers, F.; Thomas, M.; Koulakov, I. Melting at the base of the Greenland ice sheet explained by Iceland hotspot history. Nature Geoscience 2016, 9, 366-369.

59. Noel, B.; van de Berg, W.; van Meijgaard, E.; Kuipers Munneke, P.; van de Wal, R.; van den Broeke, M. Evaluation of the updated regional climate model RACMO2.3: summer snowfall impact on the Greenland Ice Sheet. The Cryosphere 2015, 9, 1831-1844.

60. Hermann, M.; Box, J.E.; Fausto, R.S.; Colgan, W.T.; Langen, P.L.; Mottram, R.; Wuite, J.; Noël, B.; van den Broeke, M.R.; van As, D. Application of PROMICE Q-Transect in Situ Accumulation and Ablation Measurements (2000-2017) to Constrain Mass Balance at the Southern Tip of the Greenland Ice Sheet. Journal of Geophysical Research: Earth Surface 2018, 123, 1235-1256.

61. Nghiem, S.V.; Hall, D.K.; Mote, T.L.; Tedesco, M.; Albert, M.R.; Keegan, K.; Shuman, C.A.; DiGirolamo, N.E.; Neumann, G. The extreme melt across the Greenland ice sheet in 2012: EXTREME MELT ACROSS GREENLAND ICE SHEET. Geophysical Research Letters 2012, 39.

62. Nilsson, J.; Vallelonga, P.; Simonsen, S.B.; Sørensen, L.S.; Forsberg, R.; Dahl-Jensen, D.; Hirabayashi, M.; Goto-Azuma, K.; Hvidberg, C.S.; Kjaer, H.A.; Satow, K. Greenland 2012 melt event effects on CryoSat-2 radar altimetry: EFFECT OF GREENLAND MELT ON CRYOSAT-2. Geophysical Research Letters 2015, 42, 3919-3926.

63. McMillan, M.; Leeson, A.; Shepherd, A.; Briggs, K.; Armitage, T.W.K.; Hogg, A.; Kuipers Munneke, P.; van den Broeke, M.; Noël, B.; van de Berg, W.J.; Ligtenberg, S.; Horwath, M.; Groh, A.; Muir, A.; Gilbert, L. A high-resolution record of Greenland mass balance: High-Resolution Greenland Mass Balance. Geophysical Research Letters 2016, 43, 7002-7010.

64. Zwally, H J..; Li, J.; Brenner, A C.; Beckley, M.; Cornejo, Helen G.; DiMarzio, J.; Giovinetto, M B.; Neumann, T. A..; Robbins, J.; Saba, J L.; Yi, D..; Wang, W.. Greenland ice sheet mass balance: distribution of increased mass loss with climate warming; 2003-07 versus 1992-2002. Journal of Glaciology 2011, 57.

65. Mottram, R.H.; Benn, D.I. Testing crevasse-depth models: a field study at Breidamerkurjokull, Iceland. Journal of Glaciology 2009, 55, 746-752.

66. Glen, J.W. The Creep of Polycrystalline Ice. Proceedings of the Royal Society A: Mathematical, Physical and Engineering Sciences 1955, 228, 519-538.

67. van der Veen, C. Fracture mechanics approach to penetration of surface crevasses on glaciers. Cold Regions Science and Technology 1998, 27, 31-47.

68. Nick, F.; Luckman, A.; Vieli, A.; Van Der Veen, C.; Van As, D.; Van De Wal, R.; Pattyn, F.; Hubbard, A.; Floricioiu, D. The response of Petermann Glacier, Greenland, to large calving events, and its future stability in the context of atmospheric and oceanic warming. Journal of Glaciology 2012, 58, 229-239.

69. Hill, E.A.; Carr, J.R.; Stokes, C.R.; Gudmundsson, G.H. Dynamic changes in outlet glaciers in northern Greenland from 1948 to 2015. The Cryosphere 2018, 12, 3243-3263. 
672 70. Mottram, R.; Nielsen, K.P.; Gleeson, E.; Yang, X. Modelling Glaciers in the HARMONIE-AROME NWP $673 \quad$ model. Advances in Science and Research 2017, 14, 323-334.

674 71. Bengtsson, L.; Andrae, U.; Aspelien, T.; Batrak, Y.; Calvo, J.; de Rooy, W.; Gleeson, E.; Hansen-Sass, 675 B.; Homleid, M.; Hortal, M.; Ivarsson, K.I.; Lenderink, G.; Niemelä, S.; Nielsen, K.P.; Onvlee, J.; 676 Rontu, L.; Samuelsson, P.; Muñoz, D.S.; Subias, A.; Tijm, S.; Toll, V.; Yang, X.; Koeltzow, M.O. The 677 HARMONIE-AROME Model Configuration in the ALADIN-HIRLAM NWP System. Monthly Weather $678 \quad$ Review 2017, 145, 1919-1935.

679 72. Forsberg, R.; Sørensen, L.; Simonsen, S. Greenland and Antarctica ice sheet mass changes and effects on 680 global sea level. In Integrative Study of the Mean Sea Level and Its Components; Springer, 2017; pp. 91-106. 